DOI

\title{
ЛЕЧЕНИЕ ГНОЙНОЙ ИНФЕКЦИИ МЯГКИХ ТКАНЕЙ: ОТ ИСТОРИИ К НАСТОЯЩЕМУ (ЛИТЕРАТУРНЫЙ ОБЗОР)
}

\section{TREATMENT OF PURIOUS INFECTION OF SOFT TISSUES: FROM HISTORY TO PRESENT (LITERATURE REVIEW)}

\author{
Э.С. Аль-Канани ${ }^{1,2}$, В.К. Гостищев ${ }^{2}$, А.Л. Ярош ${ }^{2}$, \\ А.А. Карпачев ${ }^{1,2}$, А.В. Солошенко ${ }^{1,2}$, С.В. Жарко ${ }^{1,2}$, М.С. Линник ${ }^{2}$ \\ E.S. Al-Kanani ${ }^{1,2}$, V.K. Gostishev ${ }^{2}$, A.L. Iarosh ${ }^{2}$, \\ A.A. Karpachev ${ }^{1,2}$, A.V. Soloshenko ${ }^{1,2}$, S.V. Zharko ${ }^{1,2}$, M.S. Linnik ${ }^{2}$ \\ ${ }^{1}$ ОГБУЗ «Белгородская областная клиническая больница Святителя Иоасафа», \\ Россия, 308007, г. Белгород, ул. Некрасова, 8/9 \\ 2 Белгородский государственный национальный исследовательский университет, \\ Россия, 308015, г. Белгород, ул. Победы, д. 85 \\ ${ }^{1}$ Belgorod Regional Clinical Hospital, \\ 8/9 Nekrasova St, Belgorod, 308007, Russia \\ ${ }^{2}$ Belgorod National Research University, \\ 85 Pobedy St, Belgorod, 308015, Russia \\ E-mail: yarosh_a@bsu.edu.ru
}

\begin{abstract}
Аннотация
С древнейших времен человечество занимается поиском универсального средства для лечения гнойных ран различного происхождения и локализации. И на сегодняшний день данная проблема не теряет свою актуальность. До сих пор в медицине не выработана единая стратегия лечения и ведения таких больных. Согласно статистике, примерно 35-40 \% от общего количества пациентов хирургических стационаров страдает от гнойных заболеваний кожи и мягких тканей. Основываясь на великих открытиях прошлого, опыте врачей предыдущих поколений, современные учёные изобретают новые способы терапии гнойных ран. Помимо хирургического метода лечения путем иссечения нежизнеспособных тканей, используют и физические явления, и химические вещества. Так, широко применяют ультразвуковую кавитацию, активно используют производные хиноксалина, растворы кислот, производные нитрофуранов, ферменты и др. Все эти методы значительно улучшили состояние пациентов, однако каждый из них имеет ряд недостатков. Одним из наиболее перспективных и совершенных в настоящее время считается способ лечения длительно незаживающих гнойных ран препаратами, содержащими ионы серебра. Изучение и усовершенствование этих препаратов в дальнейшем поможет снизить процент осложнений и улучшить качество жизни пациентов с гнойными ранами.
\end{abstract}

\section{Abstract}

Since ancient times, mankind has been searching for a universal remedy for the treatment of purulent wounds of various origin and localization. And, today, this problem does not lose its relevance. Until now, medicine has not developed a unified strategy for the treatment and management of such patients. According to statistics, $35-40 \%$ of the total number of patients in surgical hospitals suffer from purulent diseases of the skin and soft tissues. Based on the great discoveries of the past, the experience of doctors of previous generations, modern scientists invent new methods for treating purulent wounds. In addition to the surgical method of treatment by excision of non-viable tissues, various physical phenomena and chemicals are used. Surgeons in their daily work use ultrasound cavitation for necrectomy. Actively they use such chemical agents as quinoxaline derivatives, various acids, nitrofuran derivatives. All these methods have significantly improved the condition of patients, but each of them has a number of disadvantages. One of the most promising and perfect currently 
considered a way to treat long-term non-healing purulent wounds with preparations containing silver ions. The study and improvement of these drugs will help reduce the percentage of complications and improve the quality of life of patients with purulent wounds.

Ключевые слова: гнойные раны, некрэктомия, способы лечения гнойных ран, инфекционный процесс, ионы серебра, история хирургии.

Keywords: purulent wounds, necrectomy, methods for treating purulent wounds, infection process, silver ions, history of surgery.

Цель исследования: провести анализ современной литературы, посвященной истории лечения гнойных ран от античных времен до сегодняшних дней.

\section{Материалы и методы}

Проведен анализ различной литературы, включая современные отечественные и зарубежные источники, представленной в поисковых системах: «eLibrary», «PubMed», «Medline», «КиберЛенинка» по темам: раневой процесс, гнойные раны, современные методы лечения гнойных ран, композитные материалы, препараты, обогащенные ионами серебра, история изучения методов лечения инфекций мягких тканей. Представлена подробная история изучения лечения гнойных поражений. Проведена оценка современных методов лечения инфекций мягких тканей, освещены их особенности, а также достоинства и недостатки. Выделен наиболее перспективный способ лечения раневых дефектов с использованием композитного материала на основе монтмориллонит содержащей глины.

\section{Результаты}

История изучения вопроса этиологии, патогенеза и лечения гнойных поражений уходит корнями в далекое прошлое. Известно, что древние шумерские врачеватели около 2500 лет до н. э. использовали метод промывания раневых дефектов кожи и мягких тканей молоком и водой, а затем накладывали повязки, содержащие смесь мёда и смолы [Абаев, 2003]. В знаменитых папирусах Эберса (3 000 лет до н. э.) упоминается о применении в Древнем Египте меда, масла, вина и смолы для закрытия ран. Кроме того, египтяне сводили края раны вместе и даже накладывали швы.

Тысячелетние знания врачей Индии нашли свое воплощение в рукописях Аюрведа $(\mathrm{V}$ в. до н. э.) и «Книге жизни» Суршута (270 г. до н. э.). Исходя из информации этих источников, индийцы применяли для очищения ран и язв личинки мушек, которые они помещали внутрь раны для удаления некротизированных тканей. После этого они ушивали рану и накладывали повязку из шерстяной или шелковой ткани, пропитанной кунжутным маслом [Мирский, 2000]. В редких случаях применялась и пересадка кожных покровов [Миронов и др., 2010].

Учение о поражениях кожи активно развивалось в Греции. В знаменитом сочинении Гомера «Илиаде» встречается описание наложения повязок из морских губок. И даже скульптура отражает заинтересованность людей той эпохи вопросами лечения ран. Мастер гончарного дела Сосиас (500 г. до н. э.) на кувшине античных времен изображает сцену наложения повязки Ахилесом Патроклу [Сорокина, 2005].

Наиболее выдающимся представителем греческой медицины по праву считается Гиппократ (460-377 до н. э.). «Отец медицины» еще в те века описал клинику рожистого воспаления, флегмоны, абсцесса. Кроме того, ввел понятия первичного и вторичного заживления ран. В его трудах встречается упоминание нескольких способов дренирования ран с помощью первых металлических дренажей. После Троянской войны вышел «Гиппократов сборник» - труд, который почти до Средних веков являлся научной базой для спасения людей с гнойными заболеваниями [Миронов и др., 2010]. В другом довольно известном трактате «О древней медицине» врач описывает значение термина 
«воспаление». Гиппократ определил, что гнойный процесс возникает на фоне попадания загрязнений из воздуха, воды и почвы в рану. Уделял особое внимание обработке рук и перевязочного материала перед какими-либо манипуляциями, ввел неоспоримое утверждение гнойной хирургии - «ubi pus, ibi evacua», которое дословно переводится как «где гной, там разрез» [Абаев, 2003].

Также им были заложены основы десмургии. Он писал о том, что повязка должна плотно прилегать к телу, быть легкой и выполнять не только фиксационную функцию, но и лечебную. Ему принадлежит описание наложения спиральной, крестообразной и некоторых других повязок [Горюнов и др., 2004]. Существует повязка на голову, носящая название «шапка Гиппократа». Она применяется повсеместно в травматологии и хирургии.

Асептика и антисептика тоже зарождались под его началом. Во время операций Гиппократ использовал только кипяченую воду, заставлял обкладывать операционное поле чистой тканью [Мирский, 2000].

Эпоха расцвета Римской империи также ознаменована значимыми для современной медицины событиями. Наиболее яркими умами этого времени являются А.К. Цельс и К. Гален - их вклад неоспорим. В трактате «О медицине» Цельс (ок. 25 г. до н. э. ок. 50 г.н. э.) описал повязки из губчатого материала, пропитанные уксусом; бронзовые дренажные системы; способ остановки кровотечения путем наложения лигатуры с последующей тампонадой раны. Он первый разделил раны на «свежие» и «несвежие», что до сих пор имеет значение в выборе тактики лечения. Признаки воспаления, известные врачам всех специальностей, также были выделены им: краснота, опухоль, жар и боль [Абаев, 2003].

Пятый признак - нарушение функции - выделил другой ученый того времени Клавдий Гален (130-200). Известно, что он был лечащим врачом императора Марка Аврелия и его приближенных. Он знал несколько способов наложения швов, придумал делить раны на содержащие вещество и без вещества [Горюнов и др., 2004]. Заблуждение его было в том, что он считал гной неотъемлемой частью процесса заживления и даже придумывал способы для его возникновения. Данный принцип ошибочно использовался довольно длительное время [Миронов и др., 2010].

Но были и другие способы избавления человека от страданий. Гнойные раны лечили путем прижигания дефекта раскаленными металлами или нанесением кипящего масла. Далее на раневую поверхность накладывали смесь вина и меда, а позднее для этого стали использовать различные мази. Вплоть до конца XIX века самым распространенным перевязочным материалом была корпия, представляющая собой соединение лоскутов старой ветоши и марлевого бинта [Миронов и др., 2010; Сорокина, 2005].

Период Средневековья характеризуется не только застоем в социальной, экономической, культурной сфере, но и в медицине. Западную Европу поглотило беспрекословное следование канонам веры, по которым хирургическая помощь стала считаться грехом. Запрещалось объяснять природу болезни с помощью науки. О новых методах лечения не могло быть и речи. Только богатые землевладельцы - феодалы или рыцари - могли рассчитывать на медицинскую помощь. По новым правилам даже на поле боя не могли применяться методы «с излитием крови». Раны промывали вином и водой, закрывали тканью. Роль лекарственных средств выполняли всевозможные масла, а также продукты животного (шкуры, сало), растительного (корешки, листья растений) или минерального (глина) происхождения [Миронов, 2010; Сорокина, 2005].

В то же время страны Востока устремились в своем развитии вперед. Византийский врач Павел Эгинский (625-690) по праву считается одним из самых умелых хирургов своей эпохи. Он является автором «Дневника», где описывает не только теоретическую базу, но и дает рекомендации для практики [Мирский, 2000].

Выдающийся арабский ученый и хирург Абу-Бекр Мухаммед ибн Захария ар Рази (лат. Разес, 850-923) первым в истории совершил попытку выявить причины нагноения ран и развития вторичной инфекции. Ему принадлежит идея использования в перевязках хлопковой ваты. Его фундаментальный труд «Всеобъемлющая книга по медицине» в 25 томах и 
«Медицинская книга» в 10 томах оставили важный след в истории развития медицины. В XII веке они были переведены на латынь и разошлись по всему миру [Мирский, 2000].

«Канон врачебной науки», автором которого является Авиценна (Абу Али ибнСина, 980-1037), является наиболее полным сборником, объединяющим достижения врачей древности. Трактат содержит в себе информацию об основах лечения: повязках, лекарственных средствах, стерильности, способах ведения операций [Абаев, 2003].

Тем не менее представители некоторых Европейских стран в стесненных условиях продолжали накапливать опыт прошлых поколений и синтезировать новые знания. Одним из таких мест была Италия. Так, ученый Роджер Салернский (1177 год) после извлечения из раневого дефекта инородных тел предложил сшивать края шелковыми швами. Другой хирург, Бруно де Лонгобурго (1252 год), открыл заживление первичным и вторичным натяжением, также говорил о пользе ушивания раны. Считал, что нагноение не имеет положительного влияния на процесс заживления [Мирский, 2000]. Многие ученые были с ним согласны. Таким образом, в XIII веке мнение об обязательности образования гнойного содержимого было развеяно.

Во многом этому способствовал Анри де Мондевиль (1260-1320) - лечащий врач королей Людовика Х и Филиппа Красивого. В 1290 году вышел его труд «Хирургия», где он писал о пользе промывания, дренирования, ушивания ран с целью предотвращения нагноения. Ему принадлежит идея о перетягивании раненой конечности с целью уменьшения болевого синдрома и остановки кровотечения.

В 1340 году вышел сборник, объединяющий медицинский и хирургический опыт врачей многих поколений, «Обозрение хирургического искусства медицины», автором которого является Ги де Шолиак (1298-1368). До XVIII века этот энциклопедический трактат несколько раз переиздавался и был руководством для практических занятий студентов-медиков [Абаев, 2003].

Наряду с открытием новых способов в эпоху Возрождения продолжали господствовать средневековые порядки лечения. Раны по-прежнему повсеместно выжигались. Положение еще больше ухудшилось при распространении пороха, который способствовал быстрому нагноению ран и распространению инфекции.

Настоящий прорыв в гнойной хирургии совершил великий французский ученый Амбруаз Паре (1516-1590). В 1545 году был издан его труд, в котором он представил большое количество фактов против обработки ран прижиганием [Горюнов и др., 2004]. Он предлагал использовать в качестве санирующего средства скипидар, яичный желток, сулему. Также он практиковал наложение швов на рану. Он применял перевязку сосудов на протяжении, придуманную еще во времена Цельса [Миронов и др., 2010].

В 1546 г. Джироламо Фрокасторо выдвинул гипотезу о том, что есть заболевания, передающиеся через контакт между людьми. В качестве метода предотвращения развития инфекции он выделял важность изоляции больного [Абаев, 2003]. Эти рассуждения легли в основу современных принципов борьбы с внутригоспитальными штаммами микроорганизмов.

Немного ранее, в 1542 году, другой представитель французской школы хирургии Леонардо Боталло доказал, что распространению гнойного процесса в ране способствуют сгустки крови, инородные тела и участки некротизированной ткани [Абаев, 2003]. Ему современная наука обязана описанием метода рассечения ран.

Но настоящее развитие науки о лечении ран началось лишь в середине XVIII века во Франции. Это связано с открытием школ и университетов для изучения основ военнополевой хирургии. Во время своей работы хирург Анри-Франсуа Ледран (1685-1770) заметил, что раны заживают лучше, если ускорить отток их содержимого [Миронов и др., 2010]. Для этого он предложил видоизменять рану так, чтобы она напоминала конус. Более того, он считал необходимым рассекать перемычки и сращения внутри раны, что имеет значение и в наше время [Мирский, 2000; Ниязов и др., 2017].

Известный во всем мире П.Ж. Дезо (1744-1795) и его ученик Д.Ж. Ларрей (1766-1842) на практике стали не только рассекать, но и иссекать края раны. В качестве 
антисептика для промывания Ларрей использовал теплые солевые растворы с хлорноватистой кислотой. На поле боя использовал наложение первичных швов на раны [Абаев, 2003].

Английский врач Дж. Хантер (1728-1793) выделил отдельный вид заживления под струпом. И во время операций использовал технику наложения вторично-отсроченных швов [Миронов и др., 2010].

Несмотря на большой вклад ученых, пациенты продолжали умирать от сепсиса. Изза отсутствия научных представлений о течении процесса нагноения и необходимости антисептики не было четкого плана ведения и лечения. Основным методом при гнойных ранах конечностей по-прежнему оставались ампутации [Миронов и др., 2010].

Лишь к середине XIX века произошло обобщение опыта прошлых исследователей и новых научных открытий. Начали стремительно развиваться анатомия, физиология и биология. Ученый Е.Ю. Конгейм в 1867 году выявил характер сосудистых изменений в ране при воспалении. Отечественный ученый И.И. Мечников подробно описал фагоцитоз, тем самым заложив основы заживления раневых дефектов. Луи Пастер доказал, что распространение инфекции происходит при заселении раны патогенными агентами, которые вызывают брожение. Его последователи Р. Кох и П. Эрлих открыли возбудителей конкретных инфекций и, самое главное, методы их идентификации [Абаев, 2003; Сорокина, 2005]. Всё это дало возможность научно обосновать необходимость соблюдения правил асептики и антисептики во время всех врачебных манипуляций.

Параллельно с изучением причин и патогенеза открывались и новые горизонты в практическом лечении гнойных ран. Еще в своих работах великий русский ученый Н.И. Пирогов (1810-1881) заложил основу для ведения раненых больных. Он предложил применять наркоз и транспортную иммобилизацию в полевых условиях. Опровергал мнение о том, что инфекция распространяется только по воздуху. Считал, что главными причинами нагноения является контакт раневой поверхности с окружающими предметами и несоблюдение санитарным персоналом личной гигиены. В труде «Начала общей военнополевой хирургии» он высказывает предположение о возможности лечения гнойных ран без ампутаций, «сберегательным способом». Для этого хирург предлагал обрабатывать пораженные участки кожи спиртосодержащими растворами, проводить пальцевое исследование содержимого, извлекать инородные тела и, после заполнения полости ранения грануляционной тканью, накладывать швы [Миронов и др., 2010]. И в настоящее время эти принципы соблюдаются в условиях работы хирургических стационаров.

О необходимости соблюдать стерильность в работе с гнойными ранами писал в своем труде «Антисептический принцип в хирургической практике» Глазго Джозеф Листер (1867 год). Он является автором знаменитой карболовой повязки, состоящей из трех материалов: шелковой ткани, марли и «макинтоша» - воздухонепроницаемый прорезиненный материал. Все слои повязки были пропитаны 2-5 \% раствором карболовой кислоты. Повязка обладала прекрасным антисептическим эффектом, но вызывала раздражение в области наложения и была весьма токсична для медицинских работников, поэтому широкого распространения не получила [Миронов и др., 2010].

Известно, что к концу XIX века для предотвращения осложнений применялось около двадцати различных антисептиков. Чаще всего использовали йод, спирт, сулему, перманганат калия, ксероформ и даже нитрат серебра [Абаев, 2003]. Э. Бергман (1836-1907) и один из его учеников Шиммельбуш доказали необходимость асептики. Установили, что в работе хирурга для профилактики развития инфекции в ране все перевязочные материалы должны быть стерильными [Абаев, 2003].

Боевые действия, войны конца XIX - начала XX веков способствовали усовершенствованию перевязочных средств и методов лечения нагноений в целом. Ученый J.S. Gamgee изобрел ватно-марлевую повязку. Русский врач Л.П. Пелехин с 1868 года начал закладывать в рану тампоны из марли или льняной ткани, пропитанной антисептиком, с целью впитывания гнойного отделяемого. Также Н.В. Склифософский 
применял льняную ткань для перевязок, учитывая ее всасывающую способность. В своей работе «Физическая антисептика при лечении ран» М.В. Преображенский выделяет ряд важных свойств, которыми должен обладать идеальный перевязочный материал: гигроскопичность, всасываемость, пористость, теплопроводность, капиллярность [Ниязов и др., 2017; Преображенский, 1894].

После первой мировой войны одной из главных задач медицинской науки являлось изобретение новых антисептических средств. Были получены красный и белый стрептоцид, а также препараты сульфаниламидного ряда. Велись работы по улучшению качеств перевязочных материалов. Несмотря на это, процесс заживления ран оставался длительным и до конца неизученным [Абаев, 2003].

Во время второй мировой войны учение о лечении инфекционных ран сделало шаг вперед. Темпы заживления ран увеличились в связи с появлением антибиотиков широкого спектра действия и новых материалов для повязок на основе полимеров [Ниязов и др., 2017].

В послевоенные годы научный прогресс не остановился. В 1947 году G. Blaine изобрел пластины, содержащие альгинат кальция, которые использовал для закрытия раневого дефекта. В 1955 году R.H. Rice и его коллеги изобрели материал на основе полиэстера, который имел свойства абсорбента. Ученый G.D. Winter в своих экспериментах выявил, что скорость заживления ран зависит от уровня влажности под повязкой: чем он выше, тем больше скорость миграции эпителиальных клеток [Winter, 1962; Scales et al., 1963; Turner et al., 1986; Abrahamian et al., 2019].

Очевидно, что в основе современных методов лечения ран лежат достижения науки, техники и производства предыдущих этапов. Хирургическое удаление нежизнеспособной ткани путем иссечения является основополагающим и сейчас. Однако с середины XX века появляются альтернативные способы терапии гнойных ран. Выделяют аутолитический, ферментативный, физический (механический) и химический [Луцевич, 2011; Abrahamian et al., 2019].

При аутолизе происходит растворение некротических масс под действием веществ организма. Существенными недостатками при этом являются низкая скорость эпителизации дефекта и высокий риск осложнений. Для повышения уровня эффективности данного метода необходимо создать влажную среду путем наложения окклюзионной повязки, следить за оттоком экссудата, что не всегда удобно в повседневной работе [Луцевич, 2011].

Ферментные препараты, содержащие трипсин, бактериальную коллагеназу и другие лекарственные вещества, также используются для очищения дна ран от некротических масс. Этот метод довольно трудоемкий, так как требуются частые перевязки, и экономически затратный. При применении энзимов высокая частота осложнений в виде контактного дерматита и экземы [Глянцев и др, 1996; Глянцев, 1998; Гречко, 2009; Blok et al., 2019].

Заживлению гнойных повреждений кожи по-прежнему способствуют химические вещества. Применяют препараты, содержащие производные нитрофуранов, кислоты, окислители, производные хиноксалина. Для пролонгирования эффекта в них смачивают ватно-марлевые тампоны, которые затем помещают в полость раны. Все химические агенты могут поражать интактные участки кожи вокруг раны, что может удлинять процесс регенерации [Курбангалеев, 1985; Гречко, 2009; Abrahamian et al., 2019].

Физические методы лечения дополняют хирургические. Они включают в себя использование осмотически активных веществ, например, гипертонического раствора хлорида натрия, который увеличивает отток жидкости из раны в повязку. Основные недостатки: малая продолжительность действия и необходимость перевязок через 3-5 часов для поддержания лечебного эффекта [Кокобелян, 2003, Крюкова, 2005; Григорян, 2011; Tropinskaya et al., 2018]. Метод промывания раневого дефекта пульсирующей струей антисептиков также доказал свою эффективность, однако во время его проведения высока вероятность загрязнения перевязочного кабинета и инфицирования медицинского персонала [Маслова, 1986; Granick, 2005]. Лечение длительно 
незаживающих ран пытались осуществлять с помощью создания отрицательного давления над раневой полостью при помощи вакуум-аппарата. Но метод, в связи с технической недоработкой, широкого применения в медицинской практике не получил [Eardley, 2007; Wild, 2007; Kilic, 2009; Paula et al., 2019].

Одной из новейших методик обработки ран является УЗ-кавитация. Она способствует очищению ран от некротизированной ткани путем механической некрэктомии. Кроме того, ультразвук обладает бактерицидным и противовоспалительным действием, что способствует ускорению созревания грануляций. Обработка раны практически безболезненна, местного раздражения на здоровую ткань УЗ не оказывает, но в ходе более тщательного изучения выяснили, что процедура имеет ряд противопоказаний и нарушает процессы тромбообразования при длительном воздействии [Гостищев, 1996; Храмилин, 2004; Nelson et al., 2018].

На сегодняшний день наиболее перспективным направлением является изучение эффективности использования препаратов, содержащих ионы серебра. Его «чудодейственный» эффект заметили еще врачи античных времен. В медицине давно используется колларгол, протаргол, ляпис. Механизм действия серебра связывают с разрушением клеточных мембран возбудителей, с угнетением синтеза ДНК и РНК. Серебро является ингибитором тканевых металлопротеаз за счет торможения высвобождения ионов цинка. Препараты серебра обладают противовоспалительным, обезболивающим, гемостатическим эффектами. Известно, что серебро ускоряет процессы регенерации живой ткани, активирует ангиогенез в ране, не вызывая при этом фиброзных изменений [Armstrong, 2002; Morishima et al., 2018].

С этой точки зрения интересным является и разработанный в НИУ «БелГУ» уникальный композитный материал на основе монтмориллонит содержащей нитрат серебра глины. Согласно экспериментальным исследованиям, этот материал имеет дозированное и, более того, пролонгированное антимикробное действие. Активен в отношении штаммов микроорганизмов, которые являются основными возбудителями раневой инфекции. При его использовании значительно сокращаются сроки заживления ран и количество случаев с осложненным течением раневого процесса [Касанов и др., 2013; Буханов и др., 2014]. Все вышесказанное диктует необходимость проведения комплексных клинических исследований, направленных на оценку эффективности использования современных композиционных материалов, обогащенных ионами серебра, в местном лечении гнойных ран.

\section{Список литературы}

1. Абаев Ю.К. 2003. История раневой повязки. Медицинские новости. 6: 73-81.

2. Буханов В.Д., Везенцев А.И., Соколовский П.В., Савицкая Т.А. 2014. Антибактериальные свойства монтмориллонит содержащей глины. Научные ведомости БелГУ. Сер. Естественные науки. 3 (174), вып. 26: 98-102.

3. Глянцев С.П., Саввина Т.В., Заец Т.Л. 1996. Сравнительное изучение активности протеолитических ферментов, применяемых в хирургии для очищения гнойных ран: Бюлл. экспер. биол. и мед., 121 (6): 716-720.

4. Глянцев С.П. 1998. Повязки с протеолитическими ферментами в лечении гнойных ран: Хирургия, 12: 32-37.

5. Горюнов С.В., Ромшов Д.В., Бутивщенко И.А. 2004. Гнойная хирургия. М.: Бином, 558 с.

6. Гостищев В.К. 1996. Оперативная гнойная хирургия: Руководство для врачей. М: Медицина, 416 с.

7. Гречко В.Н. 2009. Изменение антилизоцимной активности раневой микрофлоры под влиянием газообразного озона. Медицинский альманах. 3: 57-59.

8. Григорян А.Ю. 2011. Лечение гнойных ран с применением многокомпонентных мазей на основе энтеросгеля.: Сибирский мед. журнал. 107 (12): 12-16.

9. Касанов К.Н., Попов В.А., Андреев В.А., Везенцев А.И., Пономарева Н.Ф. 2013. Модифицированный серебром монтмориллонит: получение, антимикробная активность и 
медицинское применение в биоактивных раневых покрытиях. Научные ведомости БелГУ. Сер. Медицина. Фармация. Вып. 23, 18 (161): 188-197.

10. Кокобелян А.Р. 2003. Лечение синдрома «диабетическая стопа» в зависимости от формы поражения: Нижегородский медицинский журнал. 3-4: 10-15.

11. Крюкова В.В. 2005. Патогенетическое обоснование сорбционно-аппликационной терапии гнойных ран: Автореф. дис. канд. мед. наук. Чита, 19 с.

12. Курбангалеев С.М. 1985. Гнойная инфекция в хирургии (принципы и методы лечения), 272 с.

13. Луцевич О.Э. 2011. Современный взгляд на патофизиологию и лечение гнойных ран. Хирургия. 5: 72-77.

14. Маслова С.П. 1989. Применение многокомпонентной мази диоксиколь в комплексном лечении послеродовых и послеабортных эндометритов: Автореф. дис. канд. мед. наук., 9 с.

15. Миронов В.И., Фролов А.П., Гилёва И.И. 2010. Учение о ранах, история, развитие, перспективы (часть 1). Сибирский медицинский журнал. 4: 118-122.

16. Мирский М.Б. 2000. Хирургия от древности до современности (Очерки истории). М.: 798.

17. Ниязов Б.С., Абдылдаев Н.К., Динлосан О.Р., Ниязова С.Б. 2017. Современные представления о лечении гнойных ран. Научный форум: Медицина, биология и химия: сб. ст. по материалам III междунар. науч.-практ. конф. М., Изд. «МЦНО», 1 (3): 38-49.

18. Преображенский М.Я. 1894. Физическая антисептика при лечении ран (экспериментальное исследование). СПб.: Главное воен.-мед. управление, 267 с.

19. Раны и раневая инфекция. Руководство для врачей. 1990. Под ред. М.И. Кузина, Б.М. Костючонок. 2-е изд. М.: Медицина, 592 с.

20. Сорокина Т.С. 2005. История медицины. Учебник для студ. высш. мед. учеб. заведений. 4-е изд., стер. М.: Академия, 560 с.

21. Храмилин В.Н. 2004. Метод ультразвуковой кавитации в комплексной терапии хронических ран нижних конечностей у больных сахарным диабетом. Вестник РГМУ, 6 (37): 32-37.

22. Abrahamian F.M., Sakoulas G., Tzanis E., Manley A., Steenbergen J., Das A.F., Eckburg P.B., McGovern P.C. 2019. Omadacycline for Acute Bacterial Skin and Skin Structure Infections. Clin Infect Dis. 1: 69.

23. Armstrong D.G. 2002. The use of silver as an antimicrobial. Alpha \& Omega Worlgwide, LLC, P. 11.

24. Blok R.D., Hagemans J.A.W., Burger J.W.A., Rothbarth J., van der Bilt J.D.W., Lapid O., Hompes R., Tanis P.J. 2019. Feasibility of a subcutaneous gluteal turnover flap without donor site scar for perineal closure after abdominoperineal resection for rectal cancer. Tech Coloproctol. 23 (8):751-759.

25. Eardley G.P., Brown K.V., Bonner T.Y., Green A.D., Clasper J.C. 2007. Infection in conflict wounded. Philos Trans R SocLond. 1562 (366): 570-578.

26. Granick M.S. 2005. Comparison of wound irrigation and tangential hydrodissction in bacterial clearance of contaminated wounds: result of randomized: Controlled clinical study - Eur. J. Pharmacol. 523 (1-3): 151-161.

27. Kilic A. Use of vacuum-assisted closure in the tropical treatment of surgical site infections: Acta Orthop Traumatol Turc. 2009. 43 (4): 495-503.

28. Morishima A., Inagawa H. Improvement in Protracted Wound Healing by Topical Cream Containing Lipopolysaccharide Derived from Pantoea agglomerans. Anticancer Res. 2018 Jul; 38 (7): $4375-4379$.

29. Nelson C.E., Chen A.E., Bellah R.D., Biko D.M., Ho-Fung V.M., Francavilla M.L., Xiao R., Kaplan S.L. 2018. Ultrasound features of purulent skin and soft tissue infection without abscess. Emerg Radiol. 25 (5): 505-511.

30. Paula F.M., Pinheiro E.A., Oliveira V.M., Ferreira C.M., Monreal M.T.F.D., Rolan M.D., Matos V.T.G. 2019. A case report of successful treatment of necrotizing fasciitis using negative pressure wound therapy. Medicine (Baltimore). 98 (2).

31. Scales J.T., Brit. J. 1963. Industr. Med. 20 (1): 82-94.

32. Tropinskaya O.F., Sharipov O.I., Ershova O.N., Kalinin P.L., Ismailov D.B. 2018. Intra-optic nerve and chiasmal abscess caused by methicillin-resistant Staphylococcus aureus (a case report and literature review). Zh. Vopr. Neirokhir. Im. N.N. Burdenko, 82 (6): 89-96.

33. Turner T.D., Schmidt R.J., Harding K.G. 1986. Advances in wound management. London: John Wiley \& Sons. 
34. Wild T. 2007. Vacuum therapy - basics, indication, contraindication and cost listing: Ther Umsch, 64 (9): 495-503.

35. Winter G.D. 1962. Nature. 193: 293-294.

\section{References}

1. Abaev Yu.K. 2003. Istoriya ranevoy povyazki [History of wound dressing]. Meditsinskie novosti. 6: 73-81.

2. Buhanov B.D., Vezentsev A.I., Sokolovskiy P.V., Savitskaya T.A. 2014. Antibakterialnyie svoystva montmorillonit soderzhaschey glinyi [Antibacterial properties of montmorillonite containing clay]. Nauchnyie vedomosti BelGU. Ser. Estestvennyie nauki. 3 (174), v. 26: 98-102.

3. Glyantsev S.P., Savvina T.V., Zaets T.L. 1996. Sravnitelnoe izuchenie aktivnosti proteoliticheskih fermentov, primenyaemyih $\mathrm{v}$ hirurgii dlya ochischeniya gnoynyih ran [Comparative study of the activity of proteolytic enzymes used in surgery for purifying purulent wounds]. Byull. eksper. biol. i med.; 121: 6: 716-720 p.

4. Glyantsev S.P. 1998. Povyazki s proteoliticheskimi fermentami v lechenii gnoynyih ran [Bandages with proteolytic enzymes in the treatment of purulent wounds]. Hirurgiya, 12: 32-37.

5. Goryunov S.V., Romshov D.V., Butivschenko I.A. 2004. Gnoynaya hirurgiya [Purulent surgery]. M.: Binom. 558 p.

6. Gostischev V.K. 1996. Operativnaya gnoynaya hirurgiya [Operative purulent surgery: A guide for doctors]. Rukovodstvo dlya vrachey. M: Meditsina, 416.

7. Grechko V.N. 2009. Izmenenie antilizotsimnoy aktivnosti ranevoy mikrofloryi pod vliyaniem gazoobraznogo ozona [Changes in the anti-lysozyme activity of wound microflora under the influence of gaseous ozone]. Meditsinskiy almanah. 3: 57-59.

8. Grigoryan A.Yu. 2011. Lechenie gnoynyih ran s primeneniem mnogokomponentnyih mazey na osnove enterosgelya [The treatment of purulent wounds with the use of multicomponent ointments on the basis of enterosgel]. Sibirskiy med. zhurnal. 107 (12): 12-16.

9. Kasanov K.N., Popov V.A., Andreev V.A., Vezentsev A.I., Ponomareva N.F. 2013. Modifitsirovannyiy serebrom montmorillonit: poluchenie, antimikrobnaya aktivnost i meditsinskoe primenenie $\mathrm{v}$ bioaktivnyih ranevyih pokryitiyah [Silver-modified montmorillonite: preparation, antimicrobial activity, and medical use in bioactive wound coatings]. Nauchnyie vedomosti BelGU. Ser. Meditsina. Farmatsiya. Vyip. 23, 18 (161): 188-197.

10. Kokobelyan A.R. 2003. Lechenie sindroma «diabeticheskaya stopa» v zavisimosti ot formyi porazheniya [Treatment of «diabetic foot» syndrome depending on the form of the lesion]. Nizhegorodskiy meditsinskiy zhurnal. 3-4: 10-15.

11. Kryukova V.V. 2005. Patogeneticheskoe obosnovanie sorbtsionno-applikatsionnoy terapii gnoynyih ran [Pathogenetic justification of sorption-application therapy of purulent wounds]: Avtoref. dis... kand. med. nauk. Chita, $19 \mathrm{p}$.

12. Kurbangaleev S.M. 1985. Gnoynaya infektsiya v hirurgii (printsipyi i metodyi lecheniya) [Purulent infection in surgery (principles and methods of treatment)], 272.

13. Lutsevich O.E. 2011. Sovremennyiy vzglyad na patofiziologiyu i lechenie gnoynyih ran [Modern view of pathophysiology and treatment of purulent wounds]. Hirurgiya. 5: 72-77.

14. Maslova S.P. 1989. Primenenie mnogokomponentnoy mazi dioksikol v kompleksnom lechenii poslerodovyih i posleabortnyih endometritov [The use of multicomponent ointments of dioxidal in the complex treatment of postpartum and post-abortion endometritis]: Avtoref. dis. kand. med. nauk. 9 p.

15. Mironov V.I., Frolov A.P., Gilyova I.I. 2010. Uchenie o ranah, istoriya, razvitie, perspektivyi (chast 1) [Teaching about wounds, history, development, perspectives (part 1)]. Sibirskiy meditsinskiy zhurnal. 4: 118-122.

16. Mirskiy M.B. 2000. Hirurgiya ot drevnosti do sovremennosti (Ocherki istorii) [Surgery from antiquity to the present (Essays on history)]. M.: 798.

17. Niyazov B.S., Abdyildaev N.K., Dinlosan O.R., Niyazova S.B. 2017. Sovremennyie predstavleniya o lechenii gnoynyih ran [Modern ideas about the treatment of purulent wounds. Scientific forum]. Nauchnyiy forum: Meditsina, biologiya i himiya: sb. st. po materialam III mezhdunar. nauch.prakt. konf. M., Izd. «MTsNO», 1 (3): 38-49.

18. Preobrazhenskiy M.Ya. 1894. Fizicheskaya antiseptika pri lechenii ran (eksperimentalnoe issledovanie) [Physical antiseptics in the treatment of wounds (experimental study)]. SPb.: Glavnoe voen.-med. upravlenie, $267 \mathrm{p}$. 
19. Ranyi i ranevaya infektsiya. Rukovodstvo dlya vrachey [Wounds and wound infection. A guide for physicians]. 1990. Pod red. M.I. Kuzina, B.M. Kostyuchonok. 2-e izd. M.: Meditsina, 592 p.

20. Sorokina T.S. 2005. Istoriya meditsinyi [History of medicine]. Uchebnik dlya stud. vyissh. med. ucheb. zavedeniy. - 4-e izd., ster. M.: Akademiya, 560 p.

21. Hramilin V.N. 2004. Metod ultrazvukovoy kavitatsii v kompleksnoy terapii hronicheskih ran nizhnih konechnostey u bolnyih saharnyim diabetom [Ultrasonic cavitation method in complex therapy of chronic wounds of the lower extremities in patients with diabetes mellitus]. Vestnik RGMU. 6 (37): 32-37.

22. Abrahamian F.M., Sakoulas G., Tzanis E., Manley A., Steenbergen J., Das A.F., Eckburg P.B., McGovern P.C. 2019. Omadacycline for Acute Bacterial Skin and Skin Structure Infections. Clin Infect Dis. 1: 69.

23. Armstrong D.G. 2002. The use of silver as an antimicrobial. Alpha \& Omega Worlgwide, LLC, P. 11.

24. Blok R.D., Hagemans J.A.W., Burger J.W.A., Rothbarth J., van der Bilt J.D.W., Lapid O., Hompes R., Tanis P.J. 2019. Feasibility of a subcutaneous gluteal turnover flap without donor site scar for perineal closure after abdominoperineal resection for rectal cancer. Tech Coloproctol. 23 (8): 751-759.

25. Eardley G.P., Brown K.V., Bonner T.Y., Green A.D., Clasper J.C. 2007. Infection in conflict wounded. Philos Trans R SocLond. 1562 (366): 570-578.

26. Granick M.S. 2005. Comparison of wound irrigation and tangential hydrodissction in bacterial clearance of contaminated wounds: result of randomized: Controlled clinical study - Eur. J. Pharmacol. 523 (1-3): 151-161.

27. Kilic A. Use of vacuum-assisted closure in the tropical treatment of surgical site infections: Acta Orthop Traumatol Turc. 2009. 43 (4): 495-503.

28. Morishima A., Inagawa H. Improvement in Protracted Wound Healing by Topical Cream Containing Lipopolysaccharide Derived from Pantoea agglomerans. Anticancer Res. 2018 Jul; 38(7): 4375-4379.

29. Nelson C.E., Chen A.E., Bellah R.D., Biko D.M., Ho-Fung V.M., Francavilla M.L., Xiao R., Kaplan S.L. 2018. Ultrasound features of purulent skin and soft tissue infection without abscess. Emerg Radiol. 25 (5): 505-511.

30. Paula F.M., Pinheiro E.A., Oliveira V.M., Ferreira C.M., Monreal M.T.F.D., Rolan M.D., Matos V.T.G. 2019. A case report of successful treatment of necrotizing fasciitis using negative pressure wound therapy. Medicine (Baltimore). 98 (2).

31. Scales J.T., Brit. J. 1963. Industr. Med. 20 (1): 82-94.

32. Tropinskaya O.F., Sharipov O.I., Ershova O.N., Kalinin P.L., Ismailov D.B. 2018. Intra-optic nerve and chiasmal abscess caused by methicillin-resistant Staphylococcus aureus (a case report and literature review). Zh. Vopr. Neirokhir. im. N.N. Burdenko, 82 (6): 89-96.

33. Turner T.D., Schmidt R.J., Harding K.G. 1986. Advances in wound management. London: John Wiley \& Sons.

34. Wild T. 2007. Vacuum therapy - basics, indication, contraindication and cost listing: Ther Umsch, 64 (9): 495-503.

35. Winter G.D. 1962. Nature. 193: 293-294.

\section{Ссылка для цитирования статьи For citation}

Аль-Канани Э.С., Куликовский В.Ф., Гостищев В.К., Ярош А.Л., Карпачев А.А., Солошенко А.В., Жарко С.В., Линник М.С. 2020. Лечение гнойной инфекции мягких тканей: от истории к настоящему (литературный обзор). Актуальные проблемы медицины, 43(1): 155-164. DOI

Al-Kanani E.S., Kulikovsky V.F., Gostishev V.K., Iarosh A.L., Karpachev A.A., Soloshenko A.V., Zharko S.V., Linnik M.S. 2020. Treatment of purious infection of soft tissues: from history to present (literature review). Challenges in Modern Medicine, 43(1): 155-164 (in Russian). DOI 